\title{
Telecommuting/Teleworking - Work from Home - Sebagai Solusi Efektif Mobilisasi Kerja
}

\author{
Siti Apriani Fawziah ${ }^{1}$, Irwansyah ${ }^{2}$ \\ 1,2 Magister Ilmu Komunikasi, FISIP Universitas Pelita Harapan, Staf Pengajar Ilmu Komunikasi FISIP UI \\ e-mail: ${ }^{1}$ sitiaprianif@gmail.com, ${ }^{2}$ dr.irwansyah.ma@gmail.com
}

\begin{abstract}
Abstrak - Telecommuting/teleworking adalah salah satu pilihan metode baru yang melibatkan teknologi untuk menyelesaikan suatu pekerjaan dari jarak jauh. Kategori telecommuting/teleworking - work from home sendiri terdiri atas tiga jenis yaitu home-based working, mobile working dan satellite office. Apabila dilihat dari jenis pekerjaannya, dapat disimpulkan bahwa secara umum telecommuting/teleworking lebih cocok untuk digunakan pada jenis pekerjaan yang memang membutuhkan tingkat mobilitas tinggi dan tidak diharuskan menetap di kantor. Tetapi, dengan adanya perkembangan teknologi saat ini sistem kerja telecommuting/teleworking dapat diaplikasikan bagi pekerjaan mobile maupun back office. Teknologi yang digunakan pun harus lengkap seperti IT infrastruktur, laptop, VPN dan jaringan internet nya. perusahaan akan membuat skema struktur organisasi bagian mana saja yang memang perlu untuk bekerja secara telecommuting/teleworking dan pada situasi-situasi tertentu misalnya dalam keadaan bencana alam atau adanya gejala sosial yang tidak memungkinkan pekerjanya untuk datang ke kantor dan harus tetap efektif bekerja seperti biasa. Penerapan telecommuting/teleworking pun tetap membutuhkan pengawasan dari sisi manajerial agar tidak ada pekerja yang melakukan kecurangan saat hal ini diterapkan Dengan begitu, tujuan dari penerapan telecommuting/teleworking - work from home pun dapat tercapai.
\end{abstract}

Kata Kunci: telecommuting, teleworking, teknologi

\begin{abstract}
Telecommuting/teleworking is one of the choices of new methods involving technology to complete a job remotely. The category of telecommuting/teleworking - work from home itself consists of three types, namely home-based working, mobile working and satellite office. Based on type of work, it can be concluded that in general telecommuting/teleworking is more suitable for use in types of work that do require a high level of mobility and are not required to stay in the office. However, with current technological developments the telecommuting/teleworking work system can be applied to mobile or back office work. The technology used must also be complete such as IT infrastructure, laptops, VPNs and internet networks. The company will make structure organization schemes that really need to work in telecommuting/teleworking and in urgent situations such as natural disasters or social symptoms that do not allow workers to come to the office and must continue to work from home, then the company must make their procedures regarding this so that the company's operational activities can continue as usual. The application of telecommuting/teleworking still requires supervision from the managerial side so that no workers commit fraud when this is implemented. Therefore, the goal of implementing telecommuting/teleworking - work from home can be achieved.
\end{abstract}

Keywords: telecommuting, teleworking, technology

\section{PENDAHULUAN}

Kegiatan komunikasi berlangsung dengan tujuan untuk memenuhi kebutuhan hidupnya baik dalam kehidupan sebagai individu maupun sosial. Seperti yang telah didefinisikan secara umum bahwa komunikasi merupakan interaksi yang dilakukan dengan sengaja baik itu oleh seseorang atau kelompok untuk membentuk kesamaan persepsi antara pemberi dengan penerima pesan yang didukung dengan latar belakang pengetahuan yang sama juga (Schramm, 1954).

Dalam ruang lingkup pekerjaan, komunikasi menjadi hal yang sangat penting untuk melakukan mobilisasi dan negosiasi setiap detail pekerjaan yang dilakukan. Perlunya koordinasi dengan berbagai tim dapat menjadikan suatu pekerjaan akan lebih ringan untuk diselesaikan. Saat ini, media komunikasi tidak hanya terbatas dengan kegiatan yang dilakukan secara face to face saja, tetapi juga melibatkan alat komunikasi elektronik 
seperti telepon, e-mail, social media (misalnya: whatsapp group) maupun platform chatroom khusus yang disediakan oleh perusahaan setempat. Bahkan, penggunaan social media saat ini dijadikan sebagai alat komunikasi paling praktis dan mudah untuk diakses dimanapun. Dipahami seperti itu, karena melalui social media setiap orang dapat saling sharing pengetahuan dan informasi walaupun berasal dari kelompok yang berbeda (Baruah, 2012).

Dari perpindahan mekanisme komunikasi tersebut terlihat bahwa memang tidak dapat dipungkiri perkembangan teknologi yang semakin cepat dan signifikan memberikan pengaruh besar terhadap berbagai lini kehidupan, baik itu dalam kebutuhan personal seorang individu, maupun dalam kebutuhan kelompok begitupun dengan penerapan teknologi di lingkungan industri bisnis dan usaha, serta pendidikan. Adapun dilihat dari sisi definisinya, (Pacey, 1983) membagi pengertian teknologi dalam dua bagian yaitu secara kultural dan organisasional. Dari sisi kultural, teknologi itu digunakan untuk kepentingan yang berhubungan dengan etika, norma dan tujuannya. Sedangkan dari sisi organisasional, teknologi dipandang sebagai alat yang digunakan dalam kegiatan ekonomi dan industri. Dari sisi organisasional, teknologi benarbenar dilihat secara fungsinya untuk memberikan kemudahan dan mempercepat penyelesaian pekerjaan.

Adanya komunikasi dan teknologi tentunya membutuhkan peran pengguna agar dapat dilihat sampai dimana komunikasi dan teknologi itu berkembang. Di tahap inilah masyarakat hadir sebagai penyeimbangnya. Masyarakat saling melakukan interaksi dan memiliki tujuan yang sama (Maciver \& Page, 1959). Demi mendukung interaksi tersebut, masyarakat memanfaatkan keberadaan teknologi khususnya dalam ruang lingkup pekerjaan.

Teknologi kini menjadi penunjang utama agar operasional perusahaan atau instansi dapat berjalan. Tanpa adanya teknologi, setiap pekerja tidak dapat mengakses informasi. Kembali kepada perkembangan teknologi tersebut, kini lahirlah sistem teknologi yang disebut dengan telecommuting atau disebut juga sebagai teleworking. Maksud dari telecommuting/teleworking adalah bekerja dengan menggunakan teknologi telekomunikasi untuk kepentingan suatu perusahaan dengan memberikan izin kepada seluruh karyawan yang bersangkutan untuk mengakses berbagai data perusahaan dimanapun tanpa mengharuskan fisik karyawan tersebut berada di dalam kantor (Ye, 2012).

Penerapan telecommuting/teleworking mulai dilakukan sejak tahun 1970 (Perez, Sanchez, \& Carnicer, 2002). Saat itu, porsi yang diberikan untuk bekerja dari rumah (Work From Home) dengan memanfaatkan sistem telecommuting/teleworking mulai digalakan, setidaknya satu kali dalam satu minggu. Tujuan telecommuting/teleworking diterapkan adalah untuk menjaga keamanan, keselamatan dan kesehatan setiap individu agar tetap produktif dan dapat menyelesaikan pekerjaannya masing-masing (Potter, 2003). Adanya telecommuting/teleworking ini merubah sistem kerja dari yang sebelumnya konvensional menjadi online. Hal ini membuat setiap pekerja tidak lagi terikat dengan tempat dan jam kerja yang telah diatur oleh perusahaan. Di Indonesia peraturan mengenai jam kerja diatur dalam Pasal 77 ayat 1, Undang Undang No 13 Tahun 2003 bahwa setidaknya minimal jumlah jam kerja yang diterapkan oleh perusahaan kepada masing-masing karyawannya dalam sehari adalah 8 jam kerja untuk sistem 5 hari kerja dan 7 jam kerja untuk sistem 4 hari kerja dalam satu minggu.

$$
\text { Manfaat dari penerapan }
$$

telecommuting/teleworking sendiri adalah selain dari jam kerja yang fleksibel, (Ye, 2012) menjelaskan bahwa telecommuting secara aktual dapat meningkatkan produktifitas karyawan, meningkatkan kualitas komunikasi antara karyawan dengan pelanggan, menjamin keseimbangan antara kehidupan pribadi karyawan dengan pekerjaan, mengurangi biaya-biaya pengeluaran tetap untuk operasional perusahaan seperti biaya listrik, telepon dan gedung. Selanjutnya manfaat lain dari telecommuting/teleworking adalah mengurangi kemacetan dan juga polusi udara akibat hasil dari pembakaran mesin kendaraan bermotor yang banyak digunakan saat jam berangkat dan pulang kerja (societal dimension) (Boell, Cecez, \& Campbell, 2014).

Secara logika, (Suarlan, 2017) merekomendasikan dengan banyaknya jumlah penduduk Indonesia khususnya di provinsi DKI Jakarta, kemudian permasalahan kemacetan lalu lintas yang tidak kunjung usai, sistem transportasi yang sepenuhnya belum seimbang dengan jumlah penggunanya dan gejala alam lain yang terjadi seperti banjir, penyebaran virus corona, sangat memungkinkan agar setiap perusahaan dan instansi mulai menerapkan sistem kerja telecommuting/teleworking.

Hampir di seluruh kota-kota besar di Indonesia, setiap musim hujan pasti menimbulkan efek banjir yang mana hal ini akan memberikan kerugian untuk berbagai sektor, seperti industri, pendidikan, perekonomian dan transportasi. Adanya musibah banjir yang melanda sebagian kota-kota besar di Indonesia membuat penduduknya terhalang untuk menjalankan aktivitas. Efek lain yang disebabkan oleh adanya banjir pun dapat menyebabkan kerusakan secara luas pada properti yang sudah terbangun di kota-kota besar. Dari sisi transportasi pun otomatis mengalami gangguan, beberapa jenis armada transportasi seperti Trans Jakarta, Commuter Line (KRL) mengalami gangguan dan tidak dapat beroperasi secara normal akibat jalur yang digunakan sesuai dengan arahnya terjebak banjir. 
Selain musibah bencana alam banjir, terdapat masalah sosial lain pun yang sangat amat sering terjadi di kota-kota besar di Indonesia, seperti kegiatan demonstrasi yang dilakukan oleh sekelompok massa untuk menyampaikan pendapat kepada pemerintah. Salah satu contoh kegiatan demonstrasi yang memberikan dampak negatif dan menjadi penghalang sehingga kegiatan bekerja menjadi sulit adalah kegiatan demonstrasi untuk menyampaikan pendapat mengenai hasil rancangan PERPPU KPK. Saat itu sekelompok massa yang terdiri dari mahasiswa, masyarakat umum, anggota ormas saling berkumpul di Senayan untuk saling menyampaikan pendapatnya. Tetapi apa yang terjadi sehingga dapat dikatakan kegiatan demo tersebut merugikan pihak lain? Apabila dilihat dari sisi prosedurnya, seharusnya kegiatan demonstrasi dapat berjalan dengan damai. Hal sebaliknya terjadi saat demo tersebut, bahwa kelompok massa saling memprovokasi sehingga demo pun menjadi ricuh dan mengganggu keamanan pihak lain khususnya yang akan berlalu lalang di depan gedung Senayan.

Masalah lainnya yang saat ini sedang menjadi hot issue di Indonesia adalah penyebaran virus corona (COVID 19). Saat ini berbagai media sedang booming mengenai penyebaran virus corona (COVID 19). Virus ini berasal dari salah satu kota di China, yaitu Wuhan. Virus ini menyebar ke berbagai sudut melalui sentuhan tangan manusia. Virus ini dapat menyebar ke seluruh wilayah di Indonesia dan dapat menjadi ancaman bagi kegiatan regular industri, bisnis, pendidikan, perdagangan dan lain sebagainya. Dengan adanya perkembangan yang semakin memburuk ditunjukkan dengan jumlah korban yang ter-suspect dan jumlah korban yang meninggal semakin tinggi, Presiden Republik Indonesia pun meminta kepada seluruh perusahaan swasta termasuk instansi pemerintahan dan Badan Usaha Milik Negara (BUMN) untuk menyiapkan standard operational procedure (SOP) dan menerapkan sistem kerja telecommuting/teleworking - work from home untuk seluruh karyawannya. Hal ini diterapkan dengan tujuan untuk mengurangi atau menghentikan penyebaran virus corona tersebut. Dengan adanya social distancing relationship diharapkan setiap orang dapat saling menjaga jarak saat melakukan interaksi satu sama lain dan saling menjaga kesehatan untuk tidak menularkan virus tersebut ke pihak yang lain. Dari kebijakan ini, diharapkan jumlah korban tidak bertambah menjadi lebih banyak dan korban yang telah ter-suspect dapat diobati oleh tenaga medis yang saat ini tersedia sampai sembuh.

Adanya beberapa masalah tersebut, membuat peneliti mempertimbangkan untuk melakukan pembahasan mengenai sistem kerja telecommuting/teleworking - work from home sebagai solusi apabila masalah-masalah tersebut sedang terjadi di Indonesia. Adapun penelitian sebelumnya yang sudah mencoba membahas efektivitas teleworking adalah penelitian yang dilakukan oleh (Suarlan, 2017), (Baruch, 2000), (Potter, 2003) dan (Perez, Sanchez, \& Carnicer, 2002).

\section{Komunikasi}

Seperti yang sudah kita ketahui bahwa untuk menjalani kehidupan sehari-hari, setiap individu membutuhkan komunikasi. (Schramm, 1954) bahwa komunikasi merupakan sebuah kegiatan yang sengaja dilakukan untuk membentuk kesamaan persepsi antara sumber dan penerima pesan yang ditentukan kebenarannya dengan menambahkan unsur-unsur kesamaan pengalaman, kesamaan bahasa, kesamaan latar belakang dan kesamaan budaya. Dengan adanya unsur-unsur yang sama tersebut, diharapkan maksud pesan yang diterima dapat sama atau sesuai dengan yang diharapkan oleh pengirim pesan.

$$
\text { Pada sistem kerja }
$$

telecommuting/teleworking, komunikasi yang dilakukan adalah komunikasi dengan melibatkan teknologi atau komunikasi digital, misalnya dengan menggunakan telepon, social media, dan e-mail. Pada teori yang dikembangkan oleh (Shannon, 1948) bahwa salah satu konsep penting yang perlu diperhatikan saat menggunakan media komunikasi digital atau seluler adalah adanya gangguan (noise). Adanya noise tersebut dapat menyebabkan pesan yang diterima oleh komunikan menjadi tidak sesuai dengan yang disampaikan oleh komunikator. Oleh karena itu, untuk mengurangi atau menghilangkan noise tersebut dibutuhkan suatu perantara atau transmisi untuk membuat pesan tersampaikan dengan jelas.

(Castells, Ardevol, Qiu, \& Sey, 2008) menyebutkan bahwa komunikasi mobile memiliki hubungan dengan masyarakat. (Castells, Ardevol, Qiu, \& Sey, 2008) menemukan konsep baru bagaimana network society itu terbentuk dengan bantuan media sosial. Dengan bantuan teknologi nirkabel, setiap orang dapat membangun komunikasi dimana saja dan kapan saja. Sebagaimana konsep dari Castells sendiri yang selalu mengusung ruang dan waktu. Konsep ruang mengacu bagaimana orang-orang dalam suatu organisasi yang sedang berada di lokasi berbeda dan berjauhan dapat saling mendukung adanya komunikasi dan konsep waktu maksudnya adalah bahwa setiap tindakan dalam hal ini komunikasi dapat dilakukan setiap saat.

Perluasan teknologi komunikasi tentunya memiliki efek positif dan negatif. Efek positif yang dapat dirasakan adalah menjadikan komunikasi itu murah, mudah sehingga dapat menghemat biaya. Mendekatkan jarak yang jauh, memperluas jaringan pertemanan karena tidak terbatas oleh jarak. Kebebasan berpendapat mengembangkan kreativitas karena setiap manusia akan semakin menggali informasi dan platform apa saja yang dapat 
menunjang kebutuhannya. Tidak terpaku pada waktu dan tempat, sehingga dapat dilakukan kapan saja dengan tujuan bersamaan. Hal ini sesuai dengan pemaparan (Castells, Ardevol, Qiu, \& Sey, 2008) bahwa penyebaran teknologi memiliki konsekuensi untuk kehidupan sehari-hari, kebijakan publik, strategi bisnis dan keputusan yang akan diambil oleh seseorang.

Selain media seluler, perangkat lain yang juga digunakan untuk memperat hubungan antar sesama manusia adalah komputer. Bahkan, saat ini setiap orang berlomba-lomba untuk menghasilkan ide terbaik untuk mengembangkan teknologi komputer itu sendiri untuk menarik minat dan ketertarikan masyarakat. Komputer dijadikan ladang bagi seseorang untuk melakukan komunikasi atau yang disebut dengan computer mediated communication (CMC). Teori ini bermaksud untuk memperlihatkan keunggulan yang tidak bisa didapatkan saat seseorang melakukan komunikasi tatap muka (Tong \& Walther, 2010).

(Tong \& Walther, 2010) pun menjelaskan bahwa computer mediated communication (CMC) menjadi opsi yang dapat diterapkan apabila komunikasi dilakukan oleh dua pihak yang saling berada dilokasi berbeda dan berjauhan (social distancing). Oleh karena itu, dapat kita lihat bahwa telecommuting/teleworking dapat menerapkan teori computer mediated communication sebagai landasan untuk melakukan komunikasi saat pekerjaan itu terjadi. Menurut (Kumar, Natarajan, \& Acharaya, 2017) computer mediated communication (CMC) merupakan bentuk komunikasi yang tidak hanya mengirimkan gambar secara detail ataupun teks digital saja, tetapi juga komunikasi dengan usaha untuk memberikan interpretasi terbaik dan menjadikan pesan tersebut sebagai identitas digital.

\section{Telecommuting/teleworking}

Telecommuting/teleworking hadir seolah menjadi sebutan baru dalam dunia bekerja karena mengindikasikan penggunaan teknologi untuk menyelesaikan pekerjaan dari rumah. Padahal, istilah bekerja dari rumah sendiri adalah istilah lama yang digunakan sebelum masuknya era industri digital untuk mereka yang bekerja tidak jauh dari rumah, misalnya para pekerja kerajinan lokal di lingkungan perumahan. Tapi kini, masyarakat mempraktekan kemampuannya untuk menyelesaikan pekerjaannya dengan dibantu oleh jaringan teknologi (Baruch, 2000). Dari segi waktu, telecommuting/teleworking dapat diaplikasikan untuk pekerja full time maupun pekerja paruh waktu (He \& $\mathrm{Hu}, 2014)$, formal atau informal dan dikehendaki oleh perusahaan maupun oleh pekerjanya sendiri (Uchenna, Uruakpa, \& Uche, 2018). Dimana perbedaan antara metode bekerja tradisional atau konvensional dengan telecommuting/teleworking adalah terletak pada lokasi atau tempat penggunaan teknologinya
(Suarlan, 2017). Menurut (Golden, 2006), bahwa telecommuting/teleworking menjadi sebuah sistem mediasi antara hubungan seorang pekerja dengan atasan atau manajernya, kemudian hubungan pekerja dengan sesama pekerja dan hubungan antara pekerja dengan keluarganya.

Dengan diterapkannya telecommuting/teleworking, diharapkan work life balance dapat dicapai (Ye, 2012). Selain itu, oleh (Kingma, 2016) juga ditambahkan bahwa pekerjaan itu sendiri dapat diselesaikan tidak hanya di kantor saja, melainkan di tempat lainnya, dapat dilakukan dirumah dan tidak hanya berpaku di rumah saja, untuk mengatasi jenuh dan bosan telecommuting dapat diaplikasikan juga pada suatu tempat yang lokasinya diluar rumah.

Dari jenis pekerjaannya teleworking atau telecommuting dapat dibagi menjadi tiga jenis, menurut (Perez, Sanchez, \& Carnicer, 2002) bahwa telecommuting/teleworking dapat dilihat dari jenis tempatnya yaitu, home-based teleworking, satellite offices dan mobile working. Teruntuk tipe yang pertama yaitu home-based teleworking, pada jenis ini pekerja benar-benar melakukan aktifitas regular pekerjaannya hanya di rumah. Pekerja tidak pergi ke luar rumah atau pergi ke suatu tempat untuk menyelesaikan pekerjaanya. Tipe pekerja ini biasanya erat kaitannya dengan mereka yang berkutat di bidang usaha online shop, pekerjaan yang berhubungan dengan kepenulisan dan pekerjaan lain yang tidak terlalu membutuhkan mobilitas tinggi. Tentunya untuk tipe home based teleworking, tetap membutuhkan jaringan internet dan teknologi agar operasional pekerjaannya dapat berjalan.

Tipe yang kedua adalah satellite offices. Pada tipe ini (Perez, Sanchez, \& Carnicer, 2002) memaparkan bahwa pekerja tidak lagi bekerja dirumah dan juga tidak bekerja di kantor pusat. Perusahaan mendelegasikan pekerja nya untuk bekerja di suatu tempat untuk menyelesaikan pekerjaannya baik itu lokasi kerjanya dekat maupun jauh dengan rumah. Pada jenis ini, biasanya perusahaan akan mempertimbangkan jarak antara rumah pekerja dengan lokasi pekerjaan nya. Contoh dari tipe ini adalah pekerja yang bergerak di bidang engineer atau IT yang berasal dari suatu perusahaan dan didelegasikan dalam jangka waktu tertentu untuk menyelesaikan pekerjaan di wilayah kerja kantor customer nya. Tipe ini pun sekaligus dapat mengurangi kemacetan yang terjadi di kota-kota besar, misalnya di Jakarta.

(Perez, Sanchez, \& Carnicer, 2002) menambahkan untuk tipe telecommuting/teleworking yang terakhir adalah mobile working. Tipe ini jauh lebih fleksibel karena benar-benar tidak lagi terikat dengan ruang kerja perusahaan dan waktu seperti para pekerja konvensional pada umumnya. Tipe pekerja di jenis ini, akan bekerja di rumah, hotel, kafe, kedai makan dan lainnya dengan menggunakan 
bantuan teknologi telekomunikasi (Perez, Sanchez, \& Carnicer, 2002). Di Indonesia sendiri, tipe pekerja yang memanfaatkan mobile working sebagai kebutuhan adalah mereka yang bergelut dalam bidang negosiasi dan promosi produk perusahaannya. Pekerja di bidang penjualan (marketing) akan pergi ke satu tempat dan tempat lainnya untuk menarik minat pelanggan sesuai dengan segmentasi pasar yang dituju agar citra perusahaan dan produk yang dijual oleh perusahaan dapat terjual.

\section{Network Society \& Information Society}

Pada zaman modern, tatanan masyarakat mudah sekali berubah (Suarlan, 2017). Setiap interaksi yang dilakukan antara satu individu dengan individu lain, dapat memberikan kemungkinan adanya perubahan dan inovasi. Adanya kebutuhan untuk saling memenuhi keinginan antar individu, membuat peradaban masyarakat berkembang. (Castells, Communication, Power and CounterPower in the Network Society, 2007) menambahkan bahwa jenis masyarakat jaringan (network society) adalah jenis masyarakat yang paling sesuai dengan keadaan yang mudah berubah dengan cepat untuk bekerja menggunakan sistem telecommuting/teleworking. Tipe masyarakat pada jenis ini, lebih fleksibel, lebih mampu untuk bertahan menghadapi perubahan dan lebih terstruktur dengan adanya perkembangan teknologi informasi.

Di dalam bukunya, (Castells \& Cardovo, The Network Society From Knowledge to Policy, 2005) peradaban yang terjadi pada tipe network society adalah kekuasaan dan kekayaan itu tergantung dari seberapa jauh teknologi mampu memberikan manfaat timbal balik untuk masyarakat. Teknologi itu bisa berasal dari mikroelektronika, komputer dan komunikasi digital dengan menggunakan koneksi yang terhubung ke internet. (Castells \& Cardovo, The Network Society From Knowledge to Policy, 2005) pun lebih jauh memaparkan bahwa munculnya masyarakat itu ditandai sebagai jenis masyarakat informasi (information society) atau masyarakat berpengetahuan (knowledge society).

Secara jelas, pemaparan dari (Castells \& Cardovo, The Network Society From Knowledge to Policy, 2005) tersebut sejalan dengan pendapat yang disampaikan oleh (Isazadeh, 2006), bahwa masyarakat informasi (information society) itu memiliki beberapa karakteristik diantaranya adalah (1) masyarakat bersifat global, tidak ada batasan dalam wilayah sehingga dengan didukung oleh koneksi internet, manusia tetap dapat saling berbicara dengan melihat wajah lawan bicaranya tanpa harus bertemu langsung (2) masyarakat menuntut kejujuran, mengharapkan informasi yang terbuka dan informasi yang pasti atau tidak simpang siur (3) masyarakat tipe ini diatur oleh pengetahuan dan kompetensi yang dimiliki oleh masing-masing individu untuk mengambil keputusan (4) masyarakat menganggap kehadiran informasi dan teknologi sebagai lingkungan yang baru untuk dipahami dan dipelajari dan karakteristik yang terakhir adalah (5) memberikan kesempatan yang sama atas setiap akses yang didapatkan atau tidak ada tumpang tindih.

Dengan kalimat lain, masyarakat yang mampu beradaptasi dengan perubahan teknologinya dapat dijelaskan dalam teori sistem sosioteknikal (Torraco, 2005). Teori sistem sosioteknikal adalah teori yang berusaha menjelaskan bagaimana cara untuk meningkatkan kepuasan kerja dan meningkatkan produktivitas dengan bergantung kepada orang lain, teknologi dan juga lingkungan kerja.

\section{Pekerja di Indonesia}

Secara umum, di Indonesia terdapat dua tipe pekerjaan di bidang Pemerintahan atau yang sering disebut sebagai Pegawa Negeri Sipil (PNS) dan karyawan swasta. (Suarlan, 2017) menjelaskan bahwa masing-masing tipe pekerjaan itu tidak dapat memilih untuk melakukan dan tidak melakukan telecommuting/teleworking berdasarkan kehendaknya masing-masing. Karena management perusahaan akan mempertimbangkan apakah tipe pekerja tertentu akan bekerja full time di dalam kantor atau mobile working berdasarkan tanggung jawab nya masing-masing.

Pada hari pertama bekerja, tim rekruitmen akan memperkenalkan budaya kerja perusahaan. Begitupun dengan sistem kerja yang berlaku bagi seorang karyawan dan sudah menjadi suatu hal mutlak bagi seorang pekerja untuk mengetahui dengan jelas apa saja yang menjadi hak dan kewajiban selama menjadi karyawan di perusahaan tersebut termasuk pekerja yang diberikan kepercayaan untuk bekerja dengan sistem telecommuting/teleworking. Di dalam lingkungan telecommuting/teleworking (Ye, 2012) membagi tiga aturan yang harus dipenuhi oleh pekerja tersebut yaitu karyawan itu sendiri, peralatan atau perlengkapan bekerja dan keamanan. Aspek karyawan maksudnya adalah mengedepankan etika atau perilaku karyawan saat bekerja. Peralatan atau perlengkapan yaitu mengacu kepada peralatan yang harus dibawa saat pekerjaan berlangsung, misalnya seperti laptop, modem, dokumen client visit, dan lain-lain. Selanjutnya dari sisi keamanan adalah mengenai jaminan rasa aman yang diberikan perusahaan kepada pekerja saat dalam perjalanan menuju dan dari customer termasuk didalamnya pekerja pun harus menjaga keamanan dan kerahasiaan data perusahaan yang dibawa ke customer. 


\section{METODE PENELITIAN}

Pada penelitian ini untuk mengetahui sejauh apa efektifitas dan efisiensi dari penerapan telecommuting/teleworking di Indonesia khususnya saat terjadi berbagai masalah sosial dan bencana alam di Indonesia. Penelitian ini dilakukan dengan menggunakan pendekatan kualitatif dengan melakukan desk review atau desk research. Pada dasarnya desk review adalah mengumpulkan datadata pendukung dari berbagai informasi yang sudah ada kemudian menggabungkan data-data tersebut sehingga dapat ditarik suatu kesimpulan. Misalnya dengan menggunakan teori-teori pendukung. Metode penelitian kualitatif mengandalkan teks dan gambar dalam melakukan analisis data (Creswell, 2014).

\section{HASIL DAN PEMBAHASAN}

Dari teori yang telah disebutkan diatas, maka terdapat beberapa hal utama yang menjadi dasar agar telecommuting/teleworking dapat diaplikasikan di Indonesia yaitu, teknologi pendukung telecommuting/teleworking, masyarakat dan peraturan perusahaan.

Teknologi Pendukung

Telecommuting/teleworking memang menjadi salah satu opsi untuk mengurangi kemacetan di kota-kota besar, misalnya di Jakarta. Tetapi penggunaan sistem telecommuting/teleworking pun perlu memperhatikan sisi pembangunan infrastruktur Information and Communication Technology (ICT) (Suarlan, 2017). Menurut (Suarlan, 2017) saat ini perkembangan ICT di Indonesia masih lemah dan cara untuk mengatasinya adalah Pemerintah Indonesia harus menambah nilai investasi untuk meningkatkan pembangunan infrastruktur di bidang ICT. Apabila dilihat, memang investasi ini akan mengeluarkan jumlah yang cukup besar, tetapi jika dipikirkan manfaatnya dalam jangka waktu panjang, maka dengan semakin mudahnya ICT di akses oleh siapapun, maka akan lebih memungkinkan juga sistem kerja telecommuting/teleworking berjalan di Indonesia. Hal ini selaras dengan pemaparan yang (Castells \& Cardovo, The Network Society From Knowledge to Policy, 2005) bahwa investasi di bidang IT akan memberikan dampak yang baik terhadap pertumbuhan ekonomi di masa mendatang. Pertumbuhan Teknologi Informasi dan Komunikasi akan memberikan pengaruh yang signifikan untuk berbagai bidang, khusunya keunggulan kompetitif di suatu negara.

Selain itu, salah satu yang paling penting dalam pengaplikasian telecommuting/teleworking adalah koneksi internet cepat dan efisien (Suarlan, 2017). (Ye, 2012) menjelaskan bahwa untuk menjamin telecommuting/teleworking dapat berjalan dengan lancar, diperlukan strategi pemasangan jaringan kepada seluruh pekerja agar setiap pekerja tetap dapat mengakses data-data yang berhubungan dengan pekerjaannya dimana pun. (Ye, 2012) pun menjelaskan bahwa pilihan teknologi terbaik untuk mengakomodasi kebutuhan telecommuting adalah dengan menggunakan sistem Virtual Private Network (VPN). Virtual Private Network (VPN) didefinisikan sebagai sebuah platform penengah yang aman untuk menggunakan jaringan infrastruktur telekomunikasi umum dengan tetap menjaga privasi dari data-data yang akan diakses oleh penggunanya (Jaha, Shatwan, \& Ashibani, 2008). Jadi, setiap pekerja dapat mengakses data dan sistem perusahaan tempat dia bekerja dalam kondisi apapun. Virtual Private Network ini dapat berjalan dan digunakan dimana pun disokong oleh jaringan digital (Digital Subscribe Line/DSL), kabel modem, jaringan Wi-Fi hotspot dan jaringan selular 3G/4G (Ye, 2012). Terdapat dua jenis VPN yang dapat digunakan untuk sistem kerja telecommuting/teleworking yaitu Secure Socket Layer (SSL) dan IP Security (IPSec) (Ye, 2012).

Seperti yang telah disampaikan oleh (Ye, 2012) sebelumnya, bahwa Virtual Private Network (VPN) tidak dapat berdiri sendiri. Sistem ini pun harus didukung dengan berbagai komponen, seperti jaringan Wi-Fi Hostspot. (Aggarwal, Mehendiratta, \& Vasisth, 2013) mendeskripsikan Wi-Fi Hostpot sebagai komponen penting dan menyediakan konektivitas portabel yang aman untuk dijelajahi. Selanjutnya, menurut (Aggarwal, Mehendiratta, \& Vasisth, 2013) bahwa Virtual Private Network (VPN) akan membatasi jaringan hackers, jadi jaringan yang digunakan akan lebih aman. VPN akan melakukan enkripsi seluruh data yang telah diakses diberbagai tempat yang berasal dari dan diserap oleh laptop pengguna agar tidak mudah diretas oleh hackers.

Komponen penting berikutnya adalah jaringan selular 3G/4G (Ye, 2012). Jaringan selular $3 \mathrm{G} / 4 \mathrm{G}$ adalah jenis jaringan komunikasi nirkabel yang menawarkan koneksi diantara beragam tipe jaringan tanpa menggunakan kabel fisik yang terlihat sebagai penghubungnya (Ezhilarasan \& Dinakaran, 2017). Menurut (Suarlan, 2017) teknologi yang maju sangat diperlukan dalam telecommuting/teleworking.

Telecommuting/teleworking sangat memungkinkan untuk diaplikasikan apabila infrastruktur komunikasi berkembang dengan baik, termasuk didalamnya adalah koneksi internet yang stabil dan kuat. Hal ini akan membutuhkan sebuah jaringan yang aman, perangkat keras dan berkecepatan tinggi, server dan database yang aman. Sukses atau tidaknya penerapan telecommuting/teleworking sangat bergantung dari perencanaan dan perancangan yang dibuat oleh pimpinan suatu lembaga ataupun kepala perusahaan. 
Peraturan Perusahaan (Perusahaan Swasta)

Sistem kerja telecommuting/teleworking tidak akan pernah berjalan tanpa adanya kebijakan yang dikeluarkan oleh perusahaan kepada karyawannya. Tuntutan akan adanya telecommuting/teleworking ini adalah berangkat dari harapan setiap pekerja untuk dapat bekerja dengan jam kerja dan aturan kerja yang lebih fleksibel. Dalam hal ini adalah perusahaan swasta, dimana umumnya perusahaan swasta menuntut fleksibilitas guna memperkenalkan perusahaannya kepada pihak lain. Menurut (Baruch, 2000) dapat menjadi suatu keputusan penting untuk menerapkan sistem kerja telecommuting/teleworking pada sebuah perusahaan. Efisiensi biaya dan pengurangan biaya operasional merupakan faktor yang paling utama. Dengan memanfaatkan telecommuting/teleworking dapat memperluas jangkauan pasar perusahaan, memperbanyak jenis karyawan yang akan direkrut di berbagai kota dan tentunya mengurangi penumpukkan jumlah pekerja dalam satu wilayah khususnya di kota besar seperti Jakarta.

Untuk dapat beradaptasi dengan sistem kerja telecommuting/teleworking ini tentunya pekerja harus diberikan pelatihan dari manajemen perusahaan mengenai hal apa saja yang berhubungan dengan ruang lingkup pekerjaannya. Tata cara penggunaan teknologi tersebut, tanggung jawab pekerjaan yang harus diselesaikan serta perilaku yang harus ditunjukkan kepada pihak lain saat bekerja. Oleh (Perez, Sanchez, \& Carnicer, 2002), dijelaskan bahwa sebuah perusahaan akan lebih yakin untuk memberikan kepercayaan terhadap pekerjanya yang sudah terlatih dibandingkan kepada pekerja yang sama sekali tidak mendapatkan pelatihan. (Perez, Sanchez, \& Carnicer, 2002) pun menambahkan efek domino yang dapat ditimbulkan apabila pekerja dengan sistem telecommuting/teleworking tidak diberikan pelatihan terlebih dahulu yaitu pekerja tidak dapat bekerja secara fleksibel dan mudah bingung dalam menghadapi keadaan tertentu.

Pendapat lain pun dijelaskan oleh (Ye, 2012) bahwa sukses atau tidaknya sistem telecommuting/teleworking berjalan adalah adanya pelatihan yang diberikan kepada pekerja. Para pekerja harus menerima pengetahuan dasar dan dijelaskan bagaimana cara mengoperasikan teknologi sesuai dengan kebutuhan kerjanya apabila teknologi tersebut digunakan dari rumah atau lokasi lain yang bukan di dalam kantor. Tidak hanya dalam hal penggunaan teknologi saja, secara individual pekerja itu pun harus diberikan pelatihan untuk mendengarkan dengan baik, berbicara, bertanya, memberikan solusi dan memecahkan masalah yang terjadi saat pekerjaan berlangsung. Dengan begitu, para pekerja pun dapat mengurangi rasa stress dan tertekan ketika menghadapi customer yang sulit.

Dari sisi manajerial perusahaan, dibutuhkan peraturan yang jelas untuk mengatur sistem ini agar dapat berjalan dengan semestinya. Walaupun pekerja tersebut tidak berada di kantor pusat, tetapi gerak geriknya tetap dapat terpantau dengan baik, sehingga tidak ada bentuk kecurangan apapun yang dapat merugikan perusahaan. Saat ini, di beberapa perusahaan sudah dikembangkan sistem absensi karyawan dan client visit berbasis mobile apps. Sehingga, saat seorang pekerja sedang dalam perjalanan menuju lokasi yang ditunjuk perusahaan, pekerja dapat mempertanggung jawabkan hasil kerjanya kepada manajemen perusahaan melalui aplikasi tersebut. Biasanya, aplikasi ini akan terhubung dengan GPS yang akan secara otomatis mendeteksi keberadaan pekerja sesuai dengan lokasi yang sebenarnya secara real time.

Benefit yang didapatkan oleh manajerial khususnya level manajemen menengah dengan menerapkan sistem ini adalah dapat merampingkan struktur organisasi perusahaan karena tidak ada pengawasan langsung yang harus dilakukan, semua bisa melibatkan teknologi. Sehingga, untuk satu orang dapat menjadi supervisi bagi beberapa divisi yang lain (Boell, Cecez, \& Campbell, 2014). Selain itu, manajer pun harus yakin dan berani mengambil resiko untuk memberikan legitimasi kepada pekerja yang bekerja diluar kantor. Pada saat yang sama, manager harus bisa mengatur hasil kerja karyawan dengan sistem telecommuting/teleworking ini, membangun hubungan kerja antar satu pekerja dengan pekerja lain dan tidak membeda-bedakan sistem komunikasi yang terjalin (Potter, 2003).

\section{Masyarakat}

Seluruh jenis masyarakat yang ada pada dasarnya memiliki tujuan, tetapi apa yang menjadi kelebihan dan ekstensi dari masyarakat informasi? Apabila dilihat dari karakteristik masyarakat informasi dari Isazadeh, maka tujuan adanya masyarakat informasi adalah meliputi semua tujuan dari aspek informasi. Informasi dikatakan sebagai kumpulan dari data-data. Maka, apabila masyarakat yang memiliki tujuan sebagai masyarakat informasi, masyarakat adalah sebagai pengumpul data, penganalisis data, penyebar data. Kemudian masyarakat informasi ini berkembang menjadi masyarakat virtual (virtue society) yang diartikan sebagai masyarakat yang baik (bajik). Dalam hal ini hubungannya, masyarakat virtual adalah tipe masyarakat terakhir yang memanfaatkan data. Ketika data itu diolah dengan baik dan benar, maka data itu akan menjadi bermanfaat bagi pihak lain secara digital (wisdom).

Adalah menjadi suatu pekerjaan rumah bagi pemerintah maupun swasta untuk membangun kualitas masyarakat ketika bekerja menggunakan sistem telecommuting/teleworking. Karena di Indonesia sendiri, paradigma umum yang berkembang mengenai bekerja adalah pergi ke kantor untuk bekerja selama 8 jam dan kemudian kembali pulang ke rumah. Sedangkan, pada sistem 
telecommuting/teleworking menuntut adanya fleksibilitas bagi para pekerja dan kedisiplinan. Perlunya edukasi yang diberikan kepada masyarakat pada tipe ini untuk mengubah paradigm bekerja konvensional/tradisional menjadi telecommuting/teleworking. Karena bagaimanapun, Indonesia mau tidak mau harus siap untuk menghadapi persaingan global baik itu di tingkat ASEAN maupun dunia khususnya dalam bidang tenaga kerja dan sistem ketenagakerjaan yang mana memang menuntut kemampuan tinggi agar mampu bersaing. Lalu, perlunya kesepakatan untuk menyetujui norma yang berlaku di masyarakat dan tipe tokoh yang memimpin pun harus dapat mengikuti perkembangan jaman untuk membangun kesepakatan baru sesuai dengan yang saat ini sedang berkembang.

Tujuan dari adanya perpindahan ke kehidupan digital adalah untuk berpindah dari kehidupan yang belum baik menuju kehidupan yang lebih baik. Begitupun dengan penerapan telecommuting/teleworking ini, tujuannya adalah untuk mengembangkan pola kerja yang lebih baik bagi masyarakat secara luas agar kegiatan operasional perusahaan dapat tetap berjalan dalam kondisi apapun. Selanjutnya, bagaimana hubungan pemimpin dengan masyarakat informasi? Disini pemimpin harus menyetujui informasi yang sedang terjadi.

Membangun perkembangan di masyarakat merupakan hal yang sangat penting. Jika manusia (masyarakat) tidak dibangun, tidak didorong untuk berkembang, maka akan sulit pula untuk membangun perekonomian suatu negara. Secara khusus akan membahayakan pemerintahan yang sedang berjalan. Apabila manusia (masyarakat) nya tidak berkembang, maka secara otomatis pendapatan negara pun akan sulit dan cenderung menurun dan efek domino pun akan terjadi. Contohnya, pemerintah akan kesulitan untuk menambah nilai investasi di bidang infrastruktur IT dan pendidikan, padahal pendidikan dan IT merupakan dua komponen penting dalam suatu negara. Ketika penduduk (masyarakat) dalam suatu negara memiliki pendidikan tinggi dan merata, maka kesejahteraan negara itu pun akan terjamin. Rendahnya nilai investasi pun akan memberikan dampak pada rendahnya perkembangan masyarakat. Memiliki masyarakat yang dapat berkembang dengan baik, masyarakat tidak akan memiliki persepsi tradisional lagi dan dengan cara ini, telecommuting/teleworking pun akan dapat dikembangkan di Indonesia.

\section{KESIMPULAN}

Telecommuting/teleworking adalah salah satu pilihan metode baru yang melibatkan teknologi untuk menyelesaikan suatu pekerjaan dari jarak jauh dan bukan dari kantor pusat suatu perusahaan. Kategori telecommuting/teleworking - work from home sendiri dapat dilakukan benar-benar dari rumah, dapat dilakukan di kantor yang dituju oleh perusahaan untuk didatangi dan lokasinya disesuaikan dengan jarak lokasi rumah pekerja, serta dapat dilakukan secara mobile working. Sebelum seorang pekerja terjun langsung untuk memulai pekerjaannya, maka perusahaan diwajibkan untuk memberikan pelatihan atau pengenalan terlebih dahulu. Selain itu, perlu disosialiasikan juga mengenai tiga hal utama yaitu mengenai hak dan kewajiban karyawan, peralatan apa saja yang harus dilengkapi dan dibawa saat bekerja dan keamanan data perusahaan serta keamanan pekerja itu sendiri.

Apabila dilihat dari jenis pekerjaannya, dapat disimpulkan bahwa secara umum telecommuting/teleworking lebih cocok untuk digunakan pada jenis pekerjaan yang memang membutuhkan tingkat mobilitas tinggi dan tidak diharuskan menetap di kantor, seperti pekerja yang bergelut di bidang penjualan (marketing) untuk memperkenalkan produk yang dijual perusahaan ke pihak lain, pekerja yang bertugas untuk melakukan survey kasus-kasus khusus untuk menarik kesimpulan pertumbuhan di suatu wilayah. Sementara itu, untuk jenis pekerjaan yang mengharuskan pekerjanya selalu berada dibalik meja (back office) dan berhubungan dengan pekerjaan yang bersifat administrasi untuk menunjang operasional perusahaan, tidak cocok untuk mengaplikasikan telecommuting/teleworking pada sistem kerjanya. Misalnya saja pekerja yang bergelut di bidang finance dan procurement. Tetapi, dengan adanya perkembangan teknologi saat ini sistem kerja telecommuting/teleworking dapat diaplikasikan bagi pekerjaan mobile maupun back office. Teknologi yang digunakan pun harus lengkap seperti IT infrastruktur, laptop, VPN dan jaringan internet nya.

Selanjutnya, bagi mereka yang bergelut di lembaga pemerintahan pun dapat menerapkan sistem telecommuting/teleworking. Hal tersebut sesuai dengan Undang-Undang Nomor 14 tahun 2008 tentang Keterbukaan Informasi Publik yang mengatur pengelolaan dan pelayanan informasi secara terbuka dengan meningkatkan kualitas dan tetap menjaga kerahasiaan informasi yang dikecualikan. Oleh karena itu, perusahaan akan membuat skema struktur organisasi bagian mana saja yang memang perlu untuk bekerja secara telecommuting/teleworking dan pada situasi-situasi tertentu misalnya dalam keadaan bencana alam atau adanya gejala sosial yang tidak memungkinkan pekerjanya untuk datang ke kantor dan harus tetap efektif bekerja dengan telecommuting/teleworking, maka perusahaan harus membuat prosedur tersendiri mengenai hal ini agar kegiatan operasional perusahaan tetap dapat berjalan seperti biasa. Penerapan telecommuting/teleworking pun tetap membutuhkan pengawasan dari sisi manajerial agar tidak ada pekerja yang melakukan kecurangan saat hal ini diterapkan. Bagi sebagian perusahaan yang 
menerapkan sistem telecommuting/teleworking mereka juga secara otomatis akan mengurangi ruang kerja yang biasanya akan digunakan oleh karyawan karena sebagian besar karyawannya bekerja secara mobile. Fasilitas yang akan didapatkan oleh pekerja dengan sistem ini pun harus dipertimbangkan oleh internal perusahaan. Dengan begitu, tujuan dari penerapan telecommuting/teleworking - work from home pun dapat tercapai.

\section{REFERENSI}

Aggarwal, D., Mehendiratta, P., \& Vasisth, M. (2013). Wireless Hotspots: Current Challenges and Future Directions For Next Generation Hotspot. International Journal of Engineering Sciences \& Research Technology, 3376-3378.

Baruah, T. D. (2012). Effectiveness of Social Media as a Tool of Communication and it's Potential for Technology Enabled Connections: A Micro-Level Study. International Journal of Scientific and Research Publication, 1-10.

Baruch, Y. (2000). Teleworking: Benefits and Pitfalls as Perceived by Professionals and Managers . New Technology, Work and Employment, 34-49.

Boell, S., Cecez, K., \& Campbell, J. (2014). Telework and The Nature of Work: An Assesment of Different Aspects of Work and The Role of Technology. Twenty Second European Conference on Information Systems, 1-15.

Castells, M. (2007). Communication, Power and Counter-Power in the Network Society. International Journal of Communication, 238-266.

Castells, M., \& Cardovo, G. (2005). The Network Society From Knowledge to Policy. Washington DC, USA: Center for Transatlantic Relations.

Castells, M., Ardevol, M. F., Qiu, J. L., \& Sey, A. (2008). Mobile Communication and Society: A Global Perspective. Journal of Information Technology \& Politics.

Creswell, J. W. (2014). Research Design. United States of America: SAGE Publications, Inc.

Ezhilarasan, E., \& Dinakaran, M. (2017). A Review on Mobile Technologies; 3G, 4G, and 5G. .

Golden, T. D. (2006). The Role of Relationships in Understanding Telecommuter Satisfaction. Journal of Organizational Behavior , 319340.

He, S. Y., \& Hu, L. (2014). Telecommuting, Income and Out of Home Activities Travel Behaviour and Society. Elsevier Ltd. on Behalf Of Hong Kong Society for Transportation Studies, 1-18.
Isazadeh, A. (2006). Prospectives Information Society-Optimizing Management Strategies. Appl. Comput. Math., 227-232.

Jaha, A. A., Shatwan, F. B., \& Ashibani, M. (2008). Proper Virtual Private Nerwork (VPN) Solution. The Second International Conference on Next Generation Mobile Applications, Services, and Technologies (pp. 309-314). Misurata, Libya: The Higher Institute of Industry.

Kingma, S. F. (2016). The Constituion of Third Workspace in Between The Home and The Coprorate Offie. New Technology, Work and Employment, John Willey \& Sons Ltd.

Kumar , K. A., Natarajan, S., \& Acharaya, B. (2017). Computer Mediated Communication: A Pathway to Analyze Social Media Communication Trajectories. Serial Publications, 195-205.

Pacey, A. (1983). The Culture of Technology. United States of America : MIT Press.

Perez, M. P., Sanchez, A. M., \& Carnicer, M. P. (2002). Benefits and Barriers of Telework: Perception Differences of Human Resources Manager According to Company's Operations Strategy. Technovation, 775-783.

Potter, E. E. (2003). Telecommuting: The Future of Work, Corporate Culture, and American Society. Journal of Labour Research, 7384.

Schramm, W. (1954). The Proccess Effects of Mass Communication. Urbana, IL : University of Illinois Press.

Shannon, C. E. (1948). A Mathematical Theory of Communication. The Bell System Technical Journal, 379-423.

Suarlan. (2017). Teleworking for Indonesian Civil Servants: Problems and Actos. International Journal of Administrative Science \& Organization, 100-109.

Tong, S. T., \& Walther, B. J. (2010). Just Say "No Thanks": Romantic Rejection in ComputerMediated Communication. Journal of Social and Personal Relationships, 1-19.

Torraco, R. J. (2005). Work Design Theory: A Review and Critique with Implications for Human Reseource Development . Human Resources Development Quarterly , 85109.

Uchenna, O., Uruakpa, P. C., \& Uche, E. (2018). Impact of Telecommuting on Employees Performance: A Focus on Telecommunication Out-Fits in Owerri, Imo State. Journal of Economics and Management Sciences , 54-61.

Ye, L. R. (2012). Telecommuting: Implementation for Success. International Journal of Business and Social Science, 20-29. 